\title{
Adjuvant Therapy for Early Breast Cancer
}

\author{
Muaiad Kittaneh and Stefan Glück \\ Sylvester Comprehensive Cancer Center \\ University of Miami/Leonard M. Miller School of MedicineFlorida \\ United States of America
}

\section{Introduction}

Breast cancer is the most common cause of cancer mortality among women worldwide (Key et al., 2001). There is a steady increase in the incidence of breast cancer during reproductive years with a slower rate after the age of 50 (Key et al., 2001; Collaborative Group on Hormonal Factors in Breast Cancer, 1997). Cancer of the breast is a heterogenious disease with variable response to therapy. The incidence of breast cancer among women in Europe and North America is about $2.7 \%$ by age $55,6.3 \%$ by the age of $60,5.0 \%$ by age 65 , and about $7.7 \%$ by age 75 (Collaborative Group on Hormonal Factors in Breast Cancer, 1997). This incidence is lower in developing countries and in Japan. Risk factors for developing breast cancer include family history, early menarche, nulliparity, oral contraceptives use, late age of first pregnancy, late menopause, hormone replacement therapy, alcohol, obesity, exposure to radiation and genetics including mutations in any of BRCA1, BRCA2, P53, PTEN, and ATM genes. (Kelsey\& Gammon, 1991; Key et al., 2001; Nittin, 1996; Børresen-Dale et al., 2010; Peto et al., 1999; Goldhirsch et al., 2009). Breast-feeding and moderate exercise have been reported to have a protective effect in some studies (Layde et al., 1989; Friedenreich et al., 1998). Tamoxifen and Raloxifen may be used in patients with increased risk for chemoprevention of breast cancer (Key et al., 2001; Visvanathan et al., 2009). A recent study have demonstrated that Exemestane use in postmenopausal women with moderately increased risk for breast cancer have significantly reduced invasive breast cancers after a median follow up of 3 years with no serious toxic effects and only minimal changes in health-related quality of life. Observational and metanalysis studies have shown some beneficial effect of Aspirin and other NSAID use in the prevention of occurrence as well as recurrence of breast cancer (Takkouche et al., 2008; Holmes et al., 2010). Diagnosis of breast cancer is considered early when the disease is detected in the breast only (T1-T3), or in the breast and locoregional lymph nodes (N1) and all detected disease can be removed surgically without spread to distant organs (e.g. bone, liver etc.).

\section{Biology of breast cancer}

\subsection{Molecular pathology}

Breast Cancer is a genetic disease. Mammary epithelial cells transform into malignant cells through a complex mechanism that involves a multistage process of sequential events of initiation, promotion, and progression at the genetic and epigenetic levels (Nittin, 1996). Premalignant lesions that increase the risk of malignant transformation include atypical 
ductal hyperplasia and hyperplastic alveolar nodules (Nittin, 1996; Dupont \& Page, 1985). Tamoxifen use in patients with atypical ductal hyperplasia results in a $75 \%$ risk reduction of developing invasive breast cancer (Fisher et al, 2005). Reproductive hormones are thought to influence breast cancer risk through effects on cell proliferation and DNA damage, as well as promotion of breast cancer growth. Estrogen receptor (ER) or progesterone receptor (PR)-positive and Epidermal growth factor 2, HER-2/neu, overexpressing tumors account for approximately $75 \%$ and $20 \%$ of all breast cancer cases, respectively. Half of the HER$2 /$ neu overexpressing breast cancers also expressing ER and, or PR receptors. About $15 \%$ of breast cancers lack expression of these three proteins and are named as triple-negative breast cancer. The hormone receptors status is used for histopathological classification of breast cancer as well as prediction of response to specific targeted therapeutic agents. Ki-67 is a marker of proliferation that is used in determining prognosis and identification of highrisk patients who may benefit From the addition of chemotherapy. Ki67-labelling index is considered low when it is $<15 \%$, intermediate $15-30 \%$ and high when $>30 \%$.

In the normal breast, there are three distinct types of epithelial cells: luminal or glandular cells, basal or myoepithelial cells, and stem cells. There are seven major breast cancer molecular subtypes based on patterns of gene expression and hierarchical clustering. These subtypes are: Luminal A, Luminal B, Luminal C, HER-2-enriched, Basal-like, Claudin low and Normal Breast-like group and they relate loosely to histologic and phenotypic properties and clinical outcomes.

Luminal breast cancer is called as such because of its similarity to expression of luminal breast epithelium. Luminal A tumors have the best prognosis and they make up to $40 \%$ of all breast cancers with high expression of ER-related genes, low expression of the HER-2 cluster of genes, and low expression of proliferation-related genes (Hu et al. 2006; Voduc et al., 2010; Kennecke et al., 2010). These cells have high expression of cytokeratins 8, 18 (Perou et al., 2000). The luminal B tumors are less common and have a lower expression of ERrelated genes, variable expression of Her-2 clusters and higher expression of proliferationrelated genes (Voduc et al., 2010). Molecularly, a third type known as Luminal C is distinguished from luminal subtypes $\mathrm{A}$ and $\mathrm{B}$ by its high expression of a novel set of genes with unknown function, which is a feature they share with the basal-like and HER-2 subtypes (Sorlie et al., 2001). The luminal subtype B and C seem to have a worse relapse free survival and overall survival when compared to luminal A (Sorlie et al., 2001).

The HER-2 enriched subtype is characterized by high expression of HER-2 and proliferation genes and low expression of luminal clusters. These tumors are usually HER-2 positive and ER/PR-negative. In the pre-HER-2 targeted therapy era, these tumors were associated with a poorer prognosis and a higher rate locoregional as well as metastases to the brain, liver, and lung when compared with luminal A tumors. (Voduc et al., 2010; Kennecke et al., 2010) Basal-like tumors are so called because of their similar expression to basal epithelial cells. They are typically ER/PR and HER-2/neu negative (triple negative) due to low expression of the luminal and HER2 gene clusters. There is a strong association between BRCA1 mutation and basal-like breast cancer (Sorlie et al., 2001). These cancers have a wide genomic instability, high expression of the proliferation cluster of genes and they are always of high grade. They also have high expression of the epidermal growth factor receptor (EGFR), p-cadherin, smooth muscle actin, c-kit, cytokeratins 5, 6, 14, and 17 (Maegawa \& Tang, 2010; Perou et al 2000; Sorlie et al., 2001). Basal-like tumors are associated with high risk of locoregional relapse and a higher rate of brain, lung and distant nodal metastases with lower rate of liver and bone 
metastases (Voduc et al., 2010; Kennecke et al. 2010). Luckily, these cancers are more sensitive to Anthracyclines and Taxanes (Carey et al, 2007; Maegawa \& Tang, 2010).

Claudin-low is a relatively new identified subtype of breast cancer that is characterized by the low to absent expression of luminal differentiation markers, high epithelial-tomesenchymal transition markers, immune response genes and cancer stem cell-like features (Prat et al, 2010). The majority of these tumors are ER/PR and HER-2/neu negative (triple negative) invasive ductal carcinomas with a high frequency of metaplastic and medullary differentiation. Their response rate to standard neoadjuvant chemotherapy is intermediate between that of basal-like and luminal tumors (Prat et al, 2010).

Normal breast-like tumors do not fall into any of these specific five types and they show high expression of many genes known to be expressed by adipose tissue and other nonepithelial cell types. These tumors also showed strong expression of basal epithelial genes and low expression of luminal epithelial genes (Sorlie et al., 2001).

Although metastatic breast cancer is beyond the scope of this chapter, it is worth mentioning that discordance in tumor characteristics (i.e., change in receptor status) between a primary breast cancer and sites of recurrence are common and re-biopsy of metastatic disease might be indicated especially if a long time has passed since the first diagnosis.

Other histologic Subtypes of breast cancer include secretory, adenoid cystic, tubular, medullary and lobular carcinomas.

\subsection{Screening and testing for breast cancer}

Breast cancer screening is performed in women without any signs or symptoms for early detection of breast cancer. A thorough history and detailed clinical breast examination are crucial for early detection and management of breast cancer. Symptoms or positive findings on clinical examination include a palpable lump or mass, asymmetric thickening or nodularity, nipple discharge in the absence of a palpable mass, and skin changes such as erythema, scaling, eczema, peau d'orange skin or nipple excoriation. Mammographic screening has resulted in early detection and decreased mortality from breast cancer (Humphrey et al., 2002). Ultrasonography can be a useful screening adjunct to mammography in select group of women who are young with dense breast tissue (Bevers, 2008). Breast cancer screening should be personalized and tailored to the patient age and risk factors. Asymptomatic women without any findings on physical examination should be risk stratified. Accordingly, women are either at normal or increased risk. The National Comprehensive Cancer Center (NCCN) guidelines suggest that the following women are at increased risk of breast cancer: (1) women who have previously received therapeutic thoracic or mantle irradiation; (2) women $\geq 35$ years old with a 5-year risk of invasive breast carcinoma $\geq 1.7 \%$ using the modified Gail model (3) women with a lifetime risk of breast cancer $>20 \%$ based on models largely dependent on family history; (4) women with a strong family history or genetic predisposition; (5) women with lobular carcinoma in situ (LCIS) or atypical hyperplasia; and (6) women with a prior history of breast cancer ( www.nccn.org).

Societies recommend yearly clinical breast exam (CBE) and mammograms starting at age 40 and continuing for as long as a woman is in good health. CBE every 1 to 3 years is recommended for women older than 20 and younger than 40. (Humphrey et al., 2002; Smith et al., 2003).

There is no data to support Breast self-exam (BSE) and the United States Preventive Services Task Force (USPSTF) recommends against it. Instruction in BSE has no effect on reducing breast cancer mortality (Thomas et al., 2001). 
The concept of breast self-awareness, where women should know how their breasts normally look and feel-like and report any breast changes promptly to their health care provider, has been introduced over the past several years. Periodic, consistent BSE may facilitate breast self-awareness. Premenopausal women may find BSE most informative when performed at the end of menses. A paradigm shift from SBE to breast self-awareness has been adopted over the past decade.

Screening with a MRI in addition to mammograms should be considered for women with a lifetime risk of breast cancer $>20 \%$ based on models largely dependent on family history, women who are 25 years and older with history of thoracic radiation, strong family history or genetic predisposition (i.e. BRCA mutation or first degree relative of BRCA carrier), and women with Lobular Carcinoma in Situ (LCIS). CBE every 6 to 12 months, breast awareness and risk reduction strategies should be considered in the majority of women with increased risk of breast cancer as defined earlier.

The general principles for performing genetic counselling include: (1) there is a personal or family history suggesting genetic cancer susceptibility (2) the test can be adequately interpreted and (3) the results will aid in the diagnosis or influence the medical or surgical management of the patient or family members at hereditary risk of cancer. (Robson, et al., 2010).

Treatment of early breast cancer has evolved significantly over the past two decades. In the following section, we will introduce you to adjuvant (postoperative) systemic therapy for early breast cancer. The main goal of adjuvant therapy is to reduce recurrence rate, control any potentially remaining cancer deposits and improve survival.

\section{Adjuvant therapy of early breast cancer}

Breast cancer is considered early when the disease is detected in the breast only or in the breast and its locoregional lymph nodes and all the detected disease can be removed surgically (also called operable breast cancer). Surgical management of early breast cancer is beyond the scope of this chapter. Surgical resection is performed for local control and it removes the majority of the macroscopic disease but it doesn't eradicate local and distant microscopic components. This microscopic disease places the patient at high riskof local and systemic relapse. The goal of adjuvant therapy for early breast cancer is to eradicate any hypothetical occult local or distant disease, hence reduce the risk of recurrence and improve overall survival. Adjuvant systemic treatments for early breast cancer include chemotherapy, endocrine manipulation (endocrine therapy and ovarian ablation or suppression) in hormone receptor-positive tumors, and anti HER2 agents, (e.g. trastuzumab) for HER2-positive tumors. ER-positive early breast cancer is usually treated with the combination of chemotherapy followed by endocrine therapy (e.g. tamoxifen, or Aromastase Inhibitors - AIs) in post-menopausal women (www.nccn.org, 2010; Albian, et al., 2009). Endocrine therapy alone may represent an appropriate treatment for a group of patients who do not have high-risk breast cancer or are unlikely to benefit from chemotherapy.

Clusters of gene expression analysis may offer a better insight into breast cancer subtypes and their phenotypic behavior as well as response to therapy (Perou et al., 2000; Sorlie et al., 2001). Commercially available genomic assays like MammaPrint, Oncotype Dx, Theros, Map Qaunt Dx, and Mammostrat are increasingly used for the prediction of clinical outcome in patients with breast cancer (Sotiriou \& Pusztai, 2009). Although commercially available, these assays have not been tested prospectively yet. These assays use a scoring system to classify patients as low, intermediate or high risk for disease 
recurrence using a number of different targets to identify prognosis or predict efficacy of adjuvant therapy. Several studies are exploring prospectively the power of these assays (e.g. the TAILORx trial-Trial Assigning Individualized Options for Treatment (Rx), or MINDACT trials). Until the results become available and if successful, our approach for breast cancer treatment remains broad on the basis of expected effects of different interventions in broad categories of patients.

We are witnessing a paradigm shift that will adopt a patient-tailored approach and individualized therapy for early breast cancer based on the specific tumor genetic signature of the particular cancer.

\subsection{Adjuvant endocrine therapy}

Adjuvant endocrine therapy is recommended for almost all patients whose breast cancers have any detectable estrogen receptors (Goldhirsch et al., 2009). Endocrine therapy includes the use of Selective Estrogen Receptor Modulators (SERMs) and AIs. Optimal endocrine therapy in premenopausal women with early breast cancer remains an area of controversy although tamoxifen has been adopted as a standard therapy for decades and incorporated in treatment guidelines. The benefit of adding ovarian ablation (surgically or chemically with LHRH agonists) to tamoxifen therapy remains an area of investigation. A recent meta-analysis of retrospective data indicates that each of the possible endocrine interventions has an equal role and combinations do not improve long-term outcomes. TEXT, SOFT and PERCHE trials will hopefully shed some additional light and give the treating oncologist more guidance which therapy to chose. Even the duration of tamoxifen use remains somewhat arbitrary. Studies indicate that using tamoxifen beyond 5 years might actually reduce recurrences but some of the long-term side effects might outweigh the benefits.

For postmenopausal women, third-generation aromatase inhibitors are the accepted standard to all women with ER-positive cancers. For patients already on tamoxifen, switching to an aromatase inhibitor after 2 or 3 years should be considered in patients who did not experience a recurrent disease (Goldhirsch et al., 2009). There is substantial evidence to suggest that sequential chemoendocrine combination would approximately halve the average annual death rate from breast cancer during the first 15 years after diagnosis. (Early Breast Cancer Trialists Collaborative Group, 1998, 2005). The percentage of hormone receptor positive cells is a strong predictor of response to endocrine therapy both in the adjuvant and the metastatic settings (Regan et al., 2006). About $60 \%$ of breast cancers arising in premenopausal women and $80 \%$ of those arising in postmenopausal women are ER or Progesterone receptor positive. Adjuvant endocrine therapy alone is usually advocated for breast cancers that are ER/PR positive, $\leq 2 \mathrm{~cm}$, has minimal peritumoral vascular invasion, Ki-67 $\leq 15 \%$ (low proliferation index), node negative, grade I histology, and low multigene assay score (Goldhirsch et al., 2009; Montemurro \& Aglietta, 2009). In the following section, we will describe the available hormonal therapies that are approved in the treatment of ERpositive breast cancer.

\subsubsection{Tamoxifen}

Tamoxifen is (Z)-2-[4-(1,2-diphenylbut- 1-enyl) phenoxy]-N, N- dimethylethanamine that is one of the selective estrogen receptor modulators (SERMs) and act as both an antagonist and a partial agonist of the estrogen receptor (Furr \& Jordan, 1984). Adjuvant Tamoxifen therapy 
for 5 years in women with ER positive breast cancer significantly reduces the annual recurrence, as well as breast cancer mortality in early breast cancer during the period of Tamoxifen use. (Early Breast Cancer Trialists Collaborative Group, 1998). The reduced risk of recurrence that is noticed with Tamoxifen use is solely dependent on the ER and not the PR status. (Early Breast Cancer Trialists Collaborative Group, 2005). The evidence suggests a protective carryover effect in reducing the risk of recurrence over the next few years and up to 15 years from starting Tamoxifen. Risk reduction after 5 years of Tamoxifen therapy is similar for younger and older women; however it is significantly greater for those with node positive disease in comparison to women with node-negative disease. (Early Breast Cancer Trialists Collaborative Group, 1998). The risk of thromboembolic disease and uterine cancer in women who took tamoxifen for 5 years is $0.2 \%$ per decade and is considered small in comparison to the absolute 10 -year reductions in breast cancer mortality. On the other hand, tamoxifen may have a protective effect against heart disease. Tamoxifen resistance can potentially develop due to exaggerated agonist activity with potential impairment of its antitumor activity. Tamoxifen use for more than 5 years seems to be more effective than 5 years but at a price of much higher side effect profile and the standard recommendation remains for 5 years. (Early Breast Cancer Trialists Collaborative Group, 2005; Fisher et al., 1994)

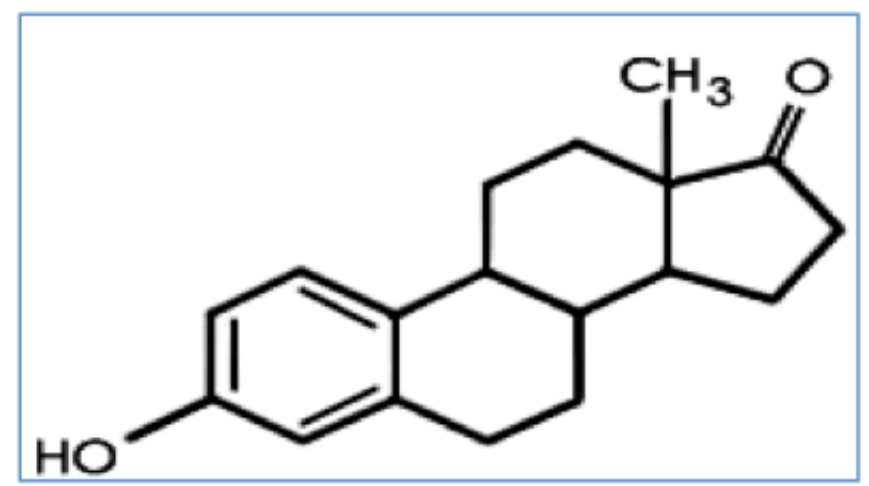

Fig. 1. Estrogen Chemical structure $\left(\mathrm{C}_{18} \mathrm{H}_{24} \mathrm{O}_{2}\right)$.

\subsubsection{Aromatase inhibitors}

In postmenopausal women, estrogen $(\mathrm{C} 18 \mathrm{H} 24 \mathrm{O} 2)$ is produced in multiple extragonadal sites that include adipose tissues, osteoblasts, chondrocytes, vascular endothelium and smooth muscle cells, adrenal gland and numerous sites in the the brain. (Figures 1 and 2) Breast adipose tissue is not an exception for this synthesis and local production of Estrogen plays an important role in breast cancer microenvironment. These tissues usually produce Estrogen for their local use (as a paracrine or intracrine factor), which results in higher tissue concentration of Estrogen. This Estrogen can also escape metabolism and enter the circulation. Postmenopausal women have a higher level of circulating testosterone (C19H28O2) in comparison to Estradiol. (Simpson, 2003). Extragonadal tissues are dependent on external source of $\mathrm{C}_{19}$ androgenic precursors, since these tissues are incapable of converting cholesterol to the $\mathrm{C}_{19}$ steroid. Those $\mathrm{C}_{19}$ precursors provide a substrate for estrogen biosynthesis in these sites. 
Aromatase is a cytochrome $\mathrm{P} 450$ enzyme that is involved in the conversion of $\mathrm{C}_{19}$ androgens to aromatic $\mathrm{C}_{18}$ estrogens (figure 2.), primarily in the ovary, and adrenal gland in females in addition to the testes in males (Santen et al., 2009; Simpson, 2003). Aromatase was recognized as a therapeutic target for the treatment of hormone-dependent breast cancer approximately 40 years ago (Santen et al., 2009). Compounds that inhibit aromatase decrease estrogen levels by affecting a key component of the production pathway, aromatase cytochrome P450. The aromatase cytochrome P450 enzyme is also active in peripheral tissues (fat, muscle, liver, and both epithelial and stromal breast cells).

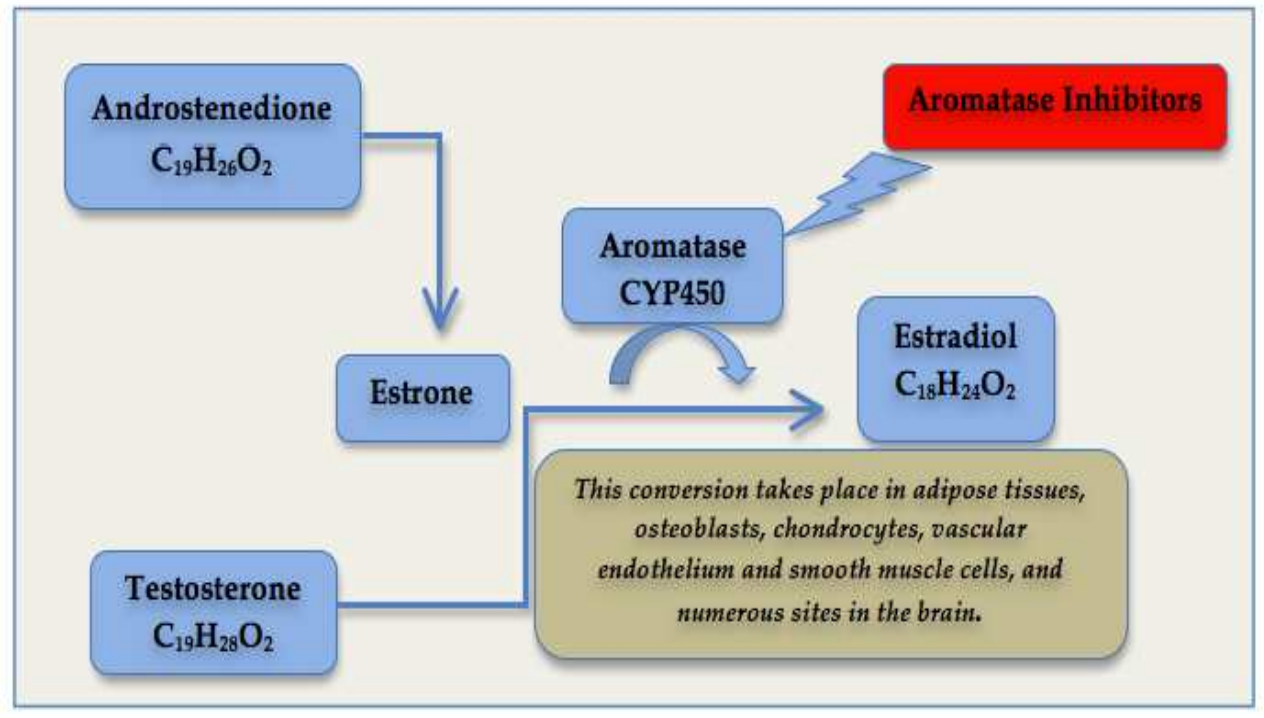

Fig. 2. Mechanism of action of Aromatase Inhibitors.

AIs are the standard of endocrine therapy for postmenopausal women with receptorpositive early, and metastatic Breast Cancer. AIs alone are contraindicated in premenopausal patients because if used alone, they do not suppress estrogen production adequately in women who are still ovulating possibly because of the interruption of the estradiol negative feedback and subsequent rise in luteinizing and follicle-stimulating hormones (Santen et al., 2009). In cases where tamoxifen is contraindicated, AIs may be administered to premenopausal women together with ovarian function suppression. In certain postmenopausal women, e.g. very low risk of recurrence, tamoxifen alone can be considered adequate.

Aminoglutethimide is considered the first generation of AIs. It is a non-selective inhibitor of adrenal steroidogenesis as well as thyroidal organification of iodine. Compared with the antiestrogen tamoxifen, aminoglutethimide had similar clinical efficacy but a higher incidence of adverse events; therefore, tamoxifen became the standard hormonal therapy for breast cancer (Harvey et al., 1982; Lipton et al., 1982; Smith et al., 1982).

More selective AIs that exhibit competitive, reversible, and/or mechanism-based inhibition were developed. The mechanism-based inhibitors produce a long lasting inhibition through their high specificty for the active enzyme site with less toxicity in comparison to with other 
competitive inhibitors (Brueggemeier, 1994; Santen et al., 2009). Mechanism-based inhibitors include the steroidal AI, exemestane, and the nonsteroidal AIs, letrozole and anastrozole. Anastrozole and letrozole are reversible inhibitors, whereas exemestane is an irreversible inhibitor.

Several clinical trials evaluating adjuvant therapy in early breast cancer have demonstrated improved disease-free survival (DFS) in postmenopausal women with the use of anastrozole, exemestane, or letrozole in comparison to tamoxifen (Boccardo et al., 2005; Coombes et al., 2007; Cuzick et al., 2010; Goss et al, 2005; Jakez et al., 2005; Kaufmann et al., 2007; Mamounas et al., 2008).

AIs have been tested in the adjuvant settings in three different scenarios: initial treatment versus tamoxifen; sequential treatment after 2-3 years of tamoxifen to finish the duration of therapy for 5 years; and extended treatment after 5 years of tamoxifen. It is controversial, as of the best timing of AI use in the treatment program after surgery. Neither the optimal timing nor the duration of therapy is well established. Some studies suggest that ER+/PgRnegative patients respond better to upfront strategy of AI. For ER+/PgR+ positive tumors, there is more uncertainty, but initial use of an AI, for say 3 years, may still be better than sequencing it after 2 years of tamoxifen, as this is the period with highest recurrence rates. An upfront strategy may be favored over sequential or extended therapy. Generally speaking, AIs have a more tolerable side effect profile than tamoxifen, with lesser incidence of thromboembolic complications, fewer hot flashes and gynecologic symptoms, but more arthralgias, myalgias and have an increased risk of osteoporosis due to it primary effect in reducing estrogen levels. The combination of Tamoxifen and AIs is not additive and leads to more side effects (Cuzick et al., 2010).

\subsection{Ovarian ablation or suppression}

Ovarian ablation in premenopausal women is achieved by surgery or irradiation and ovarian suppression is accomplished by treatment with a luteinizing-hormone releasing-hormone agonists. There is evidence to suggest a definite effect of ovarian ablation or suppression both on recurrence and mortality from breast cancer in women $<50$ years of age. (Early Breast Cancer Trialists Collaborative Group, 2005). Although tamoxifen plus ovarian function suppression is an accepted standard of endocrine therapies in premenopausal women (Goldhirsch et al., 2009), the addition of LHRH agonist to tamoxifen in this group of patients does not seem to decrease the probability of recurrence or death (Cuzick et al., 2007). In premenopausal women where tamoxifen is contraindicated, AIs with ovarian function suppression are now being tested in 3 randomized prospective clinical trials.

\subsection{Chemotherapy}

Defining the threshold for the use of cytotoxic chemotherapy is a difficult task: most RCT were performed in patients with early breast cancer who were selected on the basis of their pathological characteristics and anatomical staging, (e.g. large tumors or lymph node (LN) positive early breast cancer). The optimal duration or number of cycles to be given is not well established. Some of the factors used in decision making of chemotherapy use, include tumor size ( $\mathrm{pT}>5 \mathrm{~cm})$, high histologic grade, high proliferation index $(\mathrm{Ki}-67 \geq 10)$, vascular invasion, low expression of steroid hormone receptors, number of lymph nodes involved ( $\geq$ 4) and high multigene assay score. Ongoing research using genomic profiling assays (e.g. 
Oncotype, MammaPrint, etc.) will add to the decision making process and identify patients who may or may not benefit from systemic cytotoxic therapy. Chemotherapy is the mainstay of adjuvant treatment of patients with triple-negative disease who are at sufficient risk of relapse to justify its utilization. Studies have showed a 33\% risk reduction of recurrence as well as $26 \%$ risk reduction in mortality by using any kind of polychemotherapy in women aged 50 to 69 with ER-negative tumors. The respective reductions for patients with ER-positive tumors receiving tamoxifen were $15 \%$ for recurrence and $11 \%$ for mortality (Early Breast Cancer Trialists Collaborative Group, 2005). Patients with small primary tumors (pT1a pN0 and ER negative) might be spared adjuvant systemic therapy since the probability of recurrence is low and the potential benefit is negligible. In breast tumors that overexpress the HER-2 receptor protein (see section below), treatment with the monoclonal antibody trastuzumab, in addition to cytotoxic regimen provides incremental and significant benefits.

Identifying patients who would benefit from adjuvant chemotherapy in early breast cancer is a subject of debate. To optimize treatment of early breast cancer, it is important to understand the available chemotherapeutic agents and the advantage of choosing one over the other. There is a broad spectrum of chemotherapeutic agents available for the treatment of breast cancer and many regimens are nearly universal today. The first RCT by Bonadonna selected patients with LN positive early breast cancer after mastectomy and patients were randomized to receive chemotherapy or not. Cyclophosphamide is an alkylating agent that is used in combination with two antimetabolites, methotrexate and fluorouracil (CMF), in the treatment of early breast cancer. This combination was introduced into the management of early breast cancer in the mid-1970s and was the standard of care for some time (Bonadonna et al., 1976).

Over the last forty years, the addition of anthracyclines has been adopted as an integral part of most standard regimens. These agents inhibit tumor cell proliferation and gene expression by directly interacting with the DNA leading to the production of free radicals that destroy tumor cells. The most commonly used anthracyclines in breast cancer treatment are Doxorubicin and Epirubicin.

Adding doxorubicin to cyclophosphamide (AC combination) in the treatment of early breast cancer, proved to have equivalent efficacy to, as well as substantial advantages over, CMF in terms of tolerability, ease of administration and duration. Four cycles of $\mathrm{AC}$ was found to be equivalent to six cycles of CMF with respect to event-free survival, relapse-free survival (RFS), and overall survival (OS) in breast cancer patients regardless of nodal status, age, or estrogen-receptor (ER) status, but that AC offered the advantages of a shorter treatment course with fewer side effects (Fisher et al., 2001).

Cyclophosphamide, doxorubicin, fluorouracil (CAF) regimen have also shown similar efficacy in terms of OS when compare to CMF (Carpenter et al., 1994; Martin et al., 2003). In the subgroup of high-risk lymph node-negative patients, FAC use is associated with longer DFS and OS in comparison to CMF (Martin et al., 2003). Cyclophosphamide, Epirubicin, Fluorouracil (CEF) regimen has showed improvement in OS when compared to CMF. This benefit is true for women with node-positive disease (Levine et al., 2005; Bonneterre et al, 2005).

Anthracyclines remain important agents in adjuvant treatment and are indicated for adjuvant therapy regardless of the extent of nodal involvement, hormone receptor status, or HER-2 expression level. Anthracycline containing regimens are more effective at preventing 
recurrence and increasing survival than CMF (Cyclophosphamide, Methotrexate and 5-FU) regimens (Early Breast Cancer Trialists Collaborative Group, 2005). This is true for the major subsets of early breast cancer patients including premenopausal (age <50) and postmenopausal (age, 50-69) patients, ER-poor and ER-positive patients, and both nodenegative and node-positive patients. There is a positive correlation between delivery of the intended doses of chemotherapy on schedule and better treatment outcomes in breast cancer (Bonadonna et al., 1995; Budman et al., 1998). The optimal dose intensity in combination chemotherapy is a function of both the dose level and schedule. Minimizing the interval between cycles allows delivery of dose-dense chemotherapy (Glück, 2005).

It is believed that breast cancer growth follows Gompertzian kinetics and that shorter intervals between chemotherapy treatments allows dose-dense delivery and may result in a higher log-kill, thus leading to lower relapse rates and longer survival times (Citron et al., 2003; Norton, 1988). The use of growth factors (e.g., G-CSF) has enabled patients to tolerate dose dense chemotherapy by decreasing hematologic toxicities. Dose density and dose intensity are important part of the adjuvant treatment of early breast cancer, especially in women with node positive breast cancer.

Taxanes (docetaxel and paclitaxel) have added further survival benefit in the adjuvant treatment of early breast cancer regardless of hormone receptor status (Nowak et al., 2004; Martin et al., 2005; De Laurentiis et al., 2008). Studies comparing docetaxel, doxorubicin and cyclophosphamide (TAC) versus conventional fluorouracil, doxorubicin, and cyclophosphamide (FAC) in women with node-positive breast cancer showed a survival advantage favoring TAC (Martin et al., 2005, 2010). In addition, women with high-risk node negative disease, TAC was associated with improved rate of disease-free survival in comparison to FAC (Martin, 2010).

Sequential use of FEC followed by docetaxel (FEC-T) produced a significant DFS and OS in women 50-65 years of age with node-positive breast cancer. This regimen has become the standard of care in this age group and is considered a relatively well-tolerated regimen that contains anthracycline and taxane components. Women under the age of 50 years who received this combination did not gain a survival benefit (Roche et al., 2006).

Some studies have suggested that overexpression of HER-2 may correlate with greater sensitivity to anthracyclines. Thus the combination of trastuzumab (monoclonal antibody that inhibits signaling by HER-2 receptor) and an anthracycline-containing regimen for HER-2 positive breast cancer may confer an additional benefit in this disease subset (Paik et al., 2000; Muss et al., 1994).

Capecitabine has recently been tested in the adjuvant setting of early breast cancer. In women with medium- to high-risk early breast cancer, there was no difference in recurrence-free survival between docetaxel, capecitabine, cyclophosphamide, epirubicin (TX-CEX) versus docetaxel, cyclophosphamide, epirubicin, 5-fluorouracil (T-CEF); however, the addition of capecitabine may benefit a specific subgroup of patients with $>3$ axillary metastases or triple-negative breast cancers. The use of TX-CEX was associated with higher discontinuation rate due to toxicity (Joensuu et al., 2010). Capecitabine is still being investigated and it has not become as part of the standard therapy of early breast cancer yet.

\subsection{Targeted therapy with anti HER 2}

Trastuzumab is a humanized hybrid monoclonal antibody that selectively binds to the extracellular domain of HER-2. Its anti tumor function is not well understood but it may 
induce apoptosis, and also cause and antibody-dependent cell-mediated cytotoxicity. Trastuzumab has become an important component of breast cancer therapy regimens in metastatic as well as neoadjuvant settings of HER-2 expressing breast cancers (Salmon et al., 2001; Arteaga, 2003; Buzdar et al., 2005; Glück 2009; Dominici et al., 2010). Several large randomized clinical trials of high-risk patients with HER-2-positive early breast cancer have demonstrated that trastuzumab provides additional beneficial effects when used subsequent to anthracycline based chemotherapy and a taxane. One study also identified a nonanthracycline combination that seems to be equally effective without the cardio toxicity that is associated with anthracyclines plus trastuzumab. Several clinical trials have suggested that the addition of trastuzumab to standard chemotherapy may reduce the recurrence rate by approximately $50 \%$. The standard duration of trastuzumab therapy is 1 year, although ongoing clinical trials are testing a shorter and longer duration of therapy.

Several large randomized clinical trials of high-risk patients with HER-2-positive early breast cancer have demonstrated that trastuzumab provides additional beneficial effects when used subsequent to anthracycline- based chemotherapy and a taxane. The National Surgical Adjuvant Breast and Bowel Project protocol B-31 (NSABP-B31) and the North Central Cancer Treatment Group (NCCTG) N9831 adjuvant trials were designed to compare doxorubicin-based chemotherapy followed by paclitaxel $(\mathrm{AC} \rightarrow \mathrm{T})$ with $\mathrm{AC} \rightarrow \mathrm{T}$ plus trastuzumab either in sequence or concurrent with paclitaxel. Preliminary efficacy findings from a combined analysis of those trials after a median follow-up of 2.9 years showed more than $50 \%$ relative reduction in the risk for recurrence, with significant reductions in risk both in terms of DFS and OS with $\mathrm{AC} \rightarrow \mathrm{T}$ plus trastuzumab compared with $\mathrm{AC} \rightarrow \mathrm{T}$ (Perez et al., 2007). Doxorubicin-based chemotherapy (AC) followed by paclitaxel plus trastuzumab either in sequence or concurrent with paclitaxel reduces the risk of breast recurrence by half in addition to significant improvement in DFS and OS (Romond et al., 2005).

The trastuzumab Adjuvant (HERA) trial randomly assigned patients with HER-2-positive invasive breast cancer to receive either trastuzumab for 1 or 2 years or observation, with a primary end point of DFS; patients were previously treated with surgery and adjuvant or neoadjuvant chemotherapy (Martine et al, 2005). Unlike the NSABP-B31 and N9831 trials, most patients in the HERA trial did not receive a taxane, and about $30 \%$ of patients were node-negative. Median follow-up at 2 year after randomization demonstrated a significant improvement in disease-free survival (DFS) and overall survival (OS) in trastuzumabtreated patients, compared with observation (Smith, I et al., 2007).

The breast cancer international research group trial (BCIRG006) compared $\mathrm{AC} \rightarrow \mathrm{T}$ (Docetaxel) with AC $\rightarrow \mathrm{TH}$ (Docetaxel, Trastuzumab) and with TCH (Docetaxel, Carboplatin, Herceptin) in the adjuvant treatment of HER2-amplified early breast cancer. Trastuzumab was found to provide a similar and significant advantage for both DFS and OS when used with either anthracycline-based $(\mathrm{AC} \rightarrow \mathrm{TH})$ or non-anthracycline $(\mathrm{TCH})$ chemotherapy in both high and low-risk patients. TCH seems to have a better side effect profile in comparison of $\mathrm{AC} \rightarrow \mathrm{TH}$ (Robert et al., 2007)

The FINHER trial was originally designed to compare treatment-using docetaxel versus vinorelbine in early breast cancer. The patients were randomized to three cycles of docetaxel or vinorelbine followed by three cycles of fluorouracil, epirubicin, and cyclophosphamide. The subset of patients with HER-2-positive cancers was further randomized to either receive or not receive trastuzumab for 9 weeks together with the first three cycles of docetaxel or vinorelbine. Within this subgroup, DFS was significantly better among those who received trastuzumab and there was a trend toward better OS (Joensuu et al., 2006). 
The findings of the NSABP-B31, NCCTG-N9831, HERA, BCIRG006 and FINHER trials have established that the addition of trastuzumab to anthracycline-based chemotherapy, either with or without a taxane, may reduce the recurrence rate by approximately $50 \%$. Trastuzumab has become the standard backbone to chemotherapy in treating patients who have HER-2-overexpressing breast cancers.

New compounds that target HER2 are in development; Lapatinib is a dual erbB 1 and 2 tyrosine kinase inhibitor that blocks HER-2 receptor and has an antiproliferative effect. Lapatinib has been approved by the FDA for the use in metastatic breast cancer; these compounds are now under clinical investigation in early breast cancer. Dual HER2 blockade using trastuzumab and lapatinib to overcome resistance is a concept under investigation for treatment of HER2-positive early breast cancer (Abramson \& Arteaga, 2011). No data are available in the adjuvant setting at present time. A recent clinical trial in women with HER2positive primary breast cancer, neoadjuvant lapatinib plus trastuzumab given with paclitaxel was associated with a significant improvement in pathologic $\mathrm{CR}(\mathrm{pCR})$ rate versus trastuzumab or lapatinib with paclitaxel alone (Baselga et al., 2010).

\subsection{Radiation therapy}

Sequencing of radiotherapy in relation to chemotherapy in early breast cancer is a subject of debate and investigation. Synchronous (using CMF based chemotherapy) versus sequential chemotherapy and radiotherapy is feasible but has no advantage in reducing the risk of locoregional recurrence but it shortens the duration of adjuvant therapy.

\section{Summary and conclusion}

Breast cancer is the most common diagnosed malignancy in the western world and increasingly in the developing countries;. Early or operable breast cancer is a disease that involves the breast only or the breast and its locoregional lymph nodes. Histo-pathological diagnosis, Estrogen, Progesterone and HER-2 receptor status are important markers for prognosis and decision making in choosing the appropriate adjuvant therapy after successful surgical removal of the primary cancer. Modern molecular assays are utilizing the fact that breast cancer is a genetic and heterogeneous disease: these tests have the potential to not only better give the prognosis but also be used as predictive tests to identify effective therapeutic regimen and spare the patient unnecessary and potentially toxic treatment. As standard of practice, estrogen receptor positive cancers should be treated with hormonal therapy; the use of chemotherapy is driven by the risk of recurrence and must be carefully brought into context with its toxicity. HER-2 positive cancers are high-risk cancers regardless of size or ER status and should almost always be treated with trastuzumab in addition to chemotherapy. Anthracyclines and Taxanes containing cytotoxic combinations, as integral components of most regimens, are accepted treatment standards.

Adjuvant systemic therapy has changed the outcome of early breast cancer substantially over the last decades. Newer compounds and better understanding of the available hormonal, targeted and chemotherapeutic agents will further improve our success in treating early breast cancers.

\section{References}

Abramson, A \& Arteaga, C. L. (2011). New Strategies in HER2-Overexpressing Breast Cancer: Many Combinations of Targeted Drugs Available, Clin Cancer Res, Vol. 17, No 5, March 2011, pp. 952-958 
Albain, K. S.; Barlow, W. E; Ravdin, P. M.; Farrar, W. B.; Burton, G. V.; Ketchel, S. J.; Cobau, C. D.; Levine, E. G; Ingle, J. N. ; Pritchard, K. I.; Lichter, A. S.; Schneider, D. J.; Abeloff, M. D; Henderson, I. C.; Muss, H. B.; Green, S. J.; Lew, D.; Livingston, R. B.; Martino, S. \& Osborne, C. K. (2009). Adjuvant chemotherapy and timing of tamoxifen in postmenopausal patients with endocrine-responsive, node-positive breast cancer: a phase 3, open-label, randomized controlled trial, The Lancet, Vol. 374, Dec 2009, pp. 2055-2063

Álvarez, R.H. (2010). Present and future evolution of advanced breast cancer therapy, Breast Cancer Research, Vol. 12, No. Suppl 2, Oct 2010, pp. 1-18

Arteaga, C. L. (2003). Trastuzumab, an appropriate first-line single-agent therapy for HER2overexpressing metastatic breast cancer Breast Cancer Research, Vol. 5, No. 2, Feb 2003, pp. 96-100

Baselga, J; Bradbury, I; Eidtmann, H; et al. (2010). First Results of the NeoALTTO Trial (BIG 01-06 / EGF 106903): A Phase III, Randomized, Open Label, Neoadjuvant Study of Lapatinib, Trastuzumab, and Their Combination Plus Paclitaxel in Women with HER2-Positive Primary Breast Cancer. Presented at the 33rd Annual San Antonio Breast Cancer Symposium, December 8-12, 2010

http://www.abstracts2view.com/sabcs10/view.php?nu=SABCS10L_291\&terms= (Accessed on February 07, 2011).

Bevers, T. B. (2008). Ultrasound for the screening of breast cancer, Current Oncology Reports, Vol. 10, No. 6, Nov. 2008, pp. 527-528.

Boccardo, F.; Rubagotti, A.; Puntoni, M.; Guglielmini, P.; Amoroso, D.; Fini, A.; Paladini, G.; Mesiti, M.; Romeo, D.; Rinaldini, M.; Scali, S.; Porpiglia, M.; Benedetto, C.; Restuccia, N.; Buzzi, F.; Franchi, R.; Massidda, B.; Distante, V.; Amadori, D. \& Sismondi, P. (2005). Switching to anastrozole versus continued tamoxifen treatment of early breast cancer: preliminary results of the Italian Tamoxifen Anastrozole Trial, Journal of Clinical Oncology, Vol. 23, No. 22, Aug 2005, pp. 5138-5147.

Bonadonna, G.; Brusamolino, E.; Valagussa, P.; Rossi, A.; Brugnatelli, L.; Brambilla, C.; De Lena, M.; Tancini, G.; Bajetta, E.; Musumeci, R. \& and Veronesi, U. (1976) Combination chemotherapy as an adjuvant treatment in operable breast cancer, The New England journal of medicine, Vol. 294, No. 8, Feb 1976, pp. 405-410.

Bonadonna, G.; Valagussa, P.; Moliterni, A; Zambetti, M. \& Brambilla, C. (1995). Adjuvant cyclophosphamide, methotrexate, and fluorouracil in node-positive breast cancer: the results of 20 years of follow-up, The New England journal of medicine, Vol. 332, No. 14, Apr 1995, pp. 901-906.

Bonneterre, J.; Roche, H.; Kerbrat, P.; Bremond, A.; Fumoleau, P.; Namer, M.; Goudier, M.J.; Schraub, S.; Fargeot, P. \& Chapelle-Marcillac, I. (2005) Epirubicin increases longterm survival in adjuvant chemotherapy of patients with poor-prognosis, nodepositive, early breast cancer: 10-year follow-up results of the French Adjuvant Study Group 05 randomized trial, Journal of clinical oncology, Vol. 23, No. 12, Apr 2005, pp. 2686-2693.

Børresen-Dale, Anne-Lise et al. (2010). On the molecular biology of breast cancer, MOLECULAR ONCOLOGY, Vol. 4, Apr 2010, pp. 171-173.

Brueggemeier, R. W. (1994). Aromatase inhibitors--mechanisms of steroidal inhibitors, Breast cancer research and treatment, Vol. 30, No. 1, 1994, pp. 31-42.ISBN- 0167-6806; 01676806

Budman, D. R.; Berry, D. A.; Cirrincione, C. T.; Henderson, I. C.; Wood, W. C.; Weiss, R. B.; Ferree, C. R.; Muss, H. B.; Green, M. R.; Norton, L. and E. Frei 3rd. (1998). Dose and dose intensity as determinants of outcome in the adjuvant treatment of breast 
cancer. The Cancer and Leukemia Group B, Journal of the National Cancer Institute, Vol. 90, No. 16, Aug 1998, pp. 1205-1211.

Buzdar, A. U.; Ibrahim, N. K.; Francis, D.; Booser, D. J.; Thomas, E. S.; Theriault, R. L.; Pusztai, L.; Green, M. C.; Arun, B. K.; Giordano, S. H.; Cristofanilli, M.; Frye, D. K.; Smith, T. L.; Hunt, K. K.; Singletary, S. E.; Sahin, A. A.; Ewer, M. S.; Buchholz, T. A.; Berry, D. \& Hortobagyi, G. N. (2005). Significantly higher pathologic complete remission rate after neoadjuvant therapy with trastuzumab, paclitaxel, and epirubicin chemotherapy: results of a randomized trial in human epidermal growth factor receptor 2-positive operable breast cancer, Journal of clinical oncology, vol. 23,No. 16, Jun 2005, pp. 3676-3685.

Carey, L. A.; Claire Dees, E. \& Sawyer, L. et al., The Triple Negative Paradox: Primary Tumor Chemosensitivity of Breast Cancer Subtypes, Clin Cancer Res, Vol. 13, No. 8, Apr 2007, pp. 2329-2334

Carpenter, JT.; Velez-Garcia, E.; Aron BS et al. (1994). Five-year results of a randomized comparison of cyclophosphamide, doxorubicin (Adriamycin) and fluorouracil (CAF) vs. cyclophosphamide, methotrexate and fluorouracil (CMF) for node positive breast cancer: a Southeastern Cancer Study Group study, Proc Am Soc Clin Oncol 1994; Vol. 13:66a (Abstract \#68)

Citron, M. L.; Berry, D. A.; Cirrincione, C.; Hudis, C.; Winer, E. P.; Gradishar, W. J.; Davidson, N. E.; Martino, S.; Livingston, R.; Ingle, J. N.; Perez, E. A., Carpenter, J.; Hurd, D.; Holland, J. F.; Smith, B. L.; Sartor, C. I.; Leung, E. H.; Abrams, J.; Schilsky, R. L.; Muss, H. B. \& Norton, L. (2003). Randomized trial of dose-dense versus conventionally scheduled and sequential versus concurrent combination chemotherapy as postoperative adjuvant treatment of node-positive primary breast cancer: first report of Intergroup Trial C9741/Cancer and Leukemia Group B Trial 9741, Journal of clinical oncology, Vol. 21, No. 8, Apr 2003, pp. 1431-1439.

Collaborative Group on Hormonal Factors in Breast Cancer, Breast cancer and hormone replacement therapy: collaborative reanalysis of data from 51 epidemiological studies of 52705 women with breast cancer and 108411 women without breast cancer, The Lancet, Vol. 350, Oct 1997, pp. 1047-1059

Coombes, R. C.; Kilburn, L. S.; Snowdon, C. F.; Paridaens, R.; Coleman, R. E.; Jones, S. E.; Jassem, J.; Velde Van de C.J.; Delozier, T.; Alvarez, I.; Mastro, Del L.; Ortmann, O.; Diedrich, K.; Coates, A. S.; Bajetta, E.; Holmberg, S. B.; Dodwell, D.; Mickiewicz, E.; Andersen, J.; Lonning, P. E.; Cocconi, G.; Forbes, J.; Castiglione, M.; Stuart, N.; Stewart, A.; Fallowfield, L. J.; Bertelli, G.; Hall, E.; Bogle, R. G.; Carpentieri, M.; Colajori, E.; Subar, M.; Ireland, E. \& Bliss, J. M. (2007). Survival and safety of exemestane versus tamoxifen after 2-3 years' tamoxifen treatment (Intergroup Exemestane Study): a randomized controlled trial, The Lancet, Vol. 369, Feb 2007, PP 559-570

Cuzick, J.; Sasieni, P. \& Howell, A. (2006). Should aromatase inhibitors be used as initial adjuvant treatment or sequenced after tamoxifen?, British Journal of Cancer, Vol. 94, Jan 2006, pp. 460-464

Cuzick, J.; Ambroisine, L.; Davidson, N.; Jakesz, R.; Kaufmann, M.; Regan, M. \& Sainsbury, R. (2007). Use of luteinising-hormone-releasing hormone agonists as adjuvant treatment in premenopausal patients with hormone-receptor-positive breast cancer: a meta-analysis of individual patient data from randomized adjuvant trials, The Lancet, Volume 369, Feb 2007, pp. 1711-1723

Cuzick, J.; Sestak, I.; Baum, M.; Buzdar, A.; Howell, A.; Dowsett, M. \& Forbes, J. F. (2010). ATAC/LATTE investigators, Effect of anastrozole and tamoxifen as adjuvant 
treatment for early-stage breast cancer: 10-year analysis of the ATAC trial, The Lancet Oncology, Volume 11, Dec 2010, pp. 1135-1141

De Laurentiis, M.; Cancello, G.; D'Agostino, D.; Giuliano, M.; Giordano, A.; Montagna, E.; Lauria, R.; Forestieri, V.; Esposito, A.; Silvestro, L.; Pennacchio, R.; Criscitiello, C.; Montanino, A.; Limite, G.; Bianco, A. R. \& De Placido, S. (2008) Taxane-based combinations as adjuvant chemotherapy of early breast cancer: a meta-analysis of randomized trials, Journal of clinical oncology, Vol. 26, Jan 2008, pp. 44-53

Dominici, L. S.; Gonzalez Negron V.M.; Buzdar, A.U.; Lucci, A.; Mittendorf, E. A.; LePetross, H. T.; Babiera, G. V.; Meric-Bernstam, F.; Hunt, K. K. \& Kuerer, H. M. (2010). Cytologically proven axillary lymph node metastases are eradicated in patients receiving preoperative chemotherapy with concurrent trastuzumab for HER2-positive breast cancer, Cancer, Vol. 116, No. 12, Jan 2010, pp. 2884-2889

Dupont, WD \& Page, DL. (1985). Risk factors for breast cancer in women with proliferative breast disease, The New England journal of medicine, Vol. 312, No. 3, Jan 1985, pp. 146-151

Early Breast Cancer Trialists Collaborative Group. (1998). Tamoxifen for early breast cancer: an overview of the randomized trials, The Lancet, Vol. 351, No. 9114, May 1998, pp. 1451-1467

Early Breast Cancer Trialists Collaborative Group. (2005). Effects of chemotherapy and hormonal therapy for early breast cancer on recurrence and 15-year survival: an overview of the randomized trials, The Lancet, Vol. 365, No. 9472, May 2005, pp. 1687-1717

Fisher, B.; Costantino, JP.; Redmond, CK.; Fisher, ER.; Wickerham, DL. \& Cronin, W. (1994). Endometrial Cancer in Tamoxifen-Treated Breast Cancer Patients: Findings from NSABP B-14, Journal of the National Cancer Institute, Vol. 86, No. 7, Mar 1994, pp. 527-537

Fisher, B.; Anderson, S.; Tan-Chiu, E.; Wolmark, N.; Wickerham, D. L.; Fisher, E. R.; Dimitrov, N. V.; Atkins, J. N.; Abramson, N.; Merajver, S.; Romond, E. H.; Kardinal, C. G., Shibata, H. R.; Margolese, R. G. \& Farrar, W. B. (2001). Tamoxifen and chemotherapy for axillary node-negative, estrogen receptor-negative breast cancer: findings from National Surgical Adjuvant Breast and Bowel Project B-23, Journal of clinical oncology, Vol. 19, No.4, Feb 2001, pp. 931-942

Fisher, B.; Costantino, JP.; Wickerham, D. L.; Cecchini, R. S.; Cronin, W. M.; Robidoux, A.; Bevers, T. B.; Kavanah, M. T., Atkins, J. N.; Margolese, R. G.; Runowicz, C. D.; James, J. M.; Ford, L. G. \& Wolmark, N. (2005) Tamoxifen for the prevention of breast cancer: current status of the National Surgical Adjuvant Breast and Bowel Project P-1 study, Journal of the National Cancer Institute, Vol. 97, No.22, Nov 2005, pp. 1652-1662

Friedenreich, C. M.; Thune, I.; Brinton, L. A. \& Albanes, D. (1998). Epidemiologic issues related to the association between physical activity and breast cancer, Cancer, Vol. 83, No.3, Aug 1998, pp. 600-610

Furr, B. J. \& Jordan, V. C. (1984). The pharmacology and clinical uses of tamoxifen, Pharmacology \& therapeutics, Vol. 25, No. 2, 1984, pp. 127-205

Glück, Stefan. (2009) NOAH Study: Is It Really Setting the New Standard for Preoperative Systemic Therapy in HER2 Positive Early Breast Cancer?, Breast Diseases: A Year Book Quarterly, Vol. 20, No.2 , 2009, pp. 123-219

Glück, Stefan. (2005) Adjuvant Chemotherapy for Early Breast Cancer: Optimal Use of Epirubicin, The Oncologist, Vol. 10, No.10, Nov 2005, pp. 780-791 
Goldhirsch, A.; Ingle, J. N; Gelber, R. D.; Coates, A. S.; Thurlimann, B.; Senn, H. -J. \& Panel members. (2009). Thresholds for therapies: highlights of the St Gallen International Expert Consensus on the Primary Therapy of Early Breast Cancer 2009, Annals of Oncology, Vol. 20, No. 8, June 2009, pp. 1319-1329

Goss, P.E. et al. (2003). A Randomized Trial of Letrozole in Postmenopausal Women after Five Years of Tamoxifen Therapy for Early-Stage Breast Cancer, The New England journal of medicine, Vol. 349, No. 19, Nov 2003, pp. 1793-1802

Goss, P. E.; Ingle, J. N.; Martino, S.; Robert, N. J.; Muss, H.B.; Piccart, M.J.; Castiglione, M.; Tu, D.; Shepherd, L.E.; Pritchard, K.I.; Livingston, R. B.; Davidson, N.E.; , Norton, L.; Perez, E. A.; Abrams, J. S.; Cameron, D. A.; Palmer, M.J. \& Pater J.L. ( 2005). Randomized trial of letrozole following tamoxifen as extended adjuvant therapy in receptor-positive breast cancer: updated findings from NCIC CTG MA.17, Journal of the National Cancer Institute, Vol. 97, No. 17, July 2005, pp. 12621271

Goss, P.E. et al. (2011). Exemestane for Breast-Cancer Prevention in Postmenopausal Women. The New England journal of medicine, Vol. 1056, No. 10, Jun 2011, pp. 111

Harvey, H. A.; Lipton, A.; White, D. S.; Santen, R. J.; Boucher, A. E.; Shafik, A. S. \& Dixon R. J. (1982). Cross-over comparison of tamoxifen and aminoglutethimide in advanced breast cancer, Cancer Research, Vol. 42, No. 8S, Aug 1982, pp. 3451s-3453

Holmes, M. D.; Chen, W. Y.; Li, L.; Hertzmark, E.; Spiegelman, D. \& Hankinson, S. E. Aspirin intake and survival after breast cancer, Journal of clinical oncology, Vol. 28, No. 9, Mar 2010, pp. 1467-1472

Hu, Z.; Fan, C.; Oh, D. S.; Marron, J. S.; He, X. ; Qaqish, B. F.; Livasy, C.; Carey, L. A.; Reynolds, E.; Dressler, L.; Nobel, A.; Parker, J.; Ewend, M. G.; Sawyer, L. R.; Wu, J.; Liu, Y.; Nanda, R. ; Tretiakova, M.; Orrico Ruiz A.; Dreher, D. ; Palazzo, J. P. ; Perreard, L. ; Nelson, E. ; Mone, M. ; Hansen, H. ; Mullins, M. ; Quackenbush, J. F.; Ellis, M. J. ; Olopade, O. I. ; Bernard, P. S. \& Perou, C. M. (2006). The molecular portraits of breast tumors are conserved across microarray platforms, BMC Genomics, Vol. 96, No.7, Apr 2006, pp. 1-12.

Humphrey, L. L.; Helfand, M.; Chan, B. K \& Woolf, S.H. (2002). Breast cancer screening: a summary of the evidence for the U.S. Preventive Services Task Force, Annals of Internal Medicine, Vol. 137, No. 5, Sep 2002, pp347-360

Jakesz, R.; Jonat, W.; Gnant, M.; Mittlboeck, M.; Greil, R.; Tausch, C.; Hilfrich, J.; Kwasny, W. ; Menzel, C.; Samonigg, H.; Seifert, M.; Gademann, G.; Kaufmann, M. \& J. Wolfgang, Switching of postmenopausal women with endocrine-responsive early breast cancer to anastrozole after 2 years' adjuvant tamoxifen: combined results of ABCSG trial 8 and ARNO 95 trial, The Lancet, Vol. 366, No.9484, Aug 2005, pp. 455462

Joensuu, H.; Kellokumpu-Lehtinen, PL. \& Huovinen, R. et al. (2010). FinXX final 5-year analysis: results of the randomized, open label, phase III trial in medium-to-high risk early breast cancer, San Antonio Breast Cancer Symposium, Abstract S4-1, December 2010.

Joensuu, H.; Kellokumpu-Lehtinen, PL.; Bono, P.; Alanko, T.; Kataja, V.; Asola, R.; Utriainen, T.; Kokko, R.; Hemminki, A..; Tarkkanen, M. ; Turpeenniemi-Hujanen, T. ; Jyrkkio, S. ; Flander, M.; Helle, L.; Ingalsuo, S. ; Johansson, K. ; Jaaskelainen, A. S.; Pajunen, M. ; Rauhala, , M. ; Kaleva-Kerola, J. ; Salminen, T. ; Leinonen, M. ; Elomaa, I. \& Isola, J. (2006). Adjuvant docetaxel or vinorelbine with or without trastuzumab for 
breast cancer, The New England Journal of Medicine, Vol. 354, No.8, Feb 2006 pp. 809820

Kaufmann, M.; Jonat, W.; Hilfrich, J.; Eidtmann, H.; Gademann, G.; Zuna, I. \& von Minckwitz, G. (2007). Improved overall survival in postmenopausal women with early breast cancer after anastrozole initiated after treatment with tamoxifen compared with continued tamoxifen: the ARNO 95 Study, Journal of Clinical Oncology, Vol. 25, No 19, July 2007, pp. 2664-2670

Kelsey, J. L. \& Gammon, M. D. (1991). The Epidemiology of Breast Cancer, CA: a cancer journal for clinicians, Vol. 41, No. 3, June 1991, pp. 146-165.

Kennecke, H.; Yerushalmi, R.; Woods, R.; Cheang, M. C.; Voduc, D.; Speers, C. H.; Nielsen, T. O. \& Gelmon, K. (2010). Metastatic behavior of breast cancer subtypes, Journal of Clinical Oncology, Vol. 28, No. 20, July 2010, pp. 3271-3277

Key, T J.; Verkasalo, PK \& Banks, E. (2001). Epidemiology of breast cancer, THE Lancet Oncology, Vol. 2, No. 3, Mar 2001, pp. .133-140

Laurentiis, M.; Cancello, G.; D’Agostino, D.; Giuliano, M.; Giordano, A.; Montagna, E.; Lauria, R.; Forestieri, V.; Esposito, A.; Silvestro, L.; Pennacchio, R.; Criscitiello, C.; Montanino, A.; Limite, G.; Bianco, A.R. \& De Placido, S. ( 2008) Taxane-Based Combinations As Adjuvant Chemotherapy of Early Breast Cancer: A MetaAnalysis of Randomized Trials, Journal of Clinical Oncology, Vol. 26, No. 1, Jan 2008, pp. 44-53

Layde, PM.; Webster, LA.; Baughman, AL.; Wingo, PA.; Rubin, GL. \& Ory, HW. (1998). The independent associations of parity, age at first full term pregnancy, and duration of breastfeeding with the risk of breast cancer. Cancer and Steroid Hormone Study Group, J Clin Epidemiol, Vol. 42, No.10, 1998, pp. 963-973

Levine, M. N.; Pritchard, K. I.; Bramwell, V. H.; Shepherd, L. E.; Tu, D.; Paul, N. \& National Cancer Institute of Canada Clinical Trials Group, Randomized trial comparing cyclophosphamide, epirubicin, and fluorouracil with cyclophosphamide, methotrexate, and fluorouracil in premenopausal women with node-positive breast cancer: update of National Cancer Institute of Canada Clinical Trials Group Trial MA5, Journal of clinical oncology, Vol. 23, No. 22, Aug 2005, pp. 5166-5170.

Lipton, A.; Harvey, H. A.; Santen, R. J.; Boucher, A.; White, D.; Bernath A.; Dixon, , R. ; Richards, G. \& Shafik, A. (1982). A randomized trial of aminoglutethimide versus tamoxifen in metastatic breast cancer, Cancer, Vol. 50, No.11, Aug 1982, pp. 22652268

Maegawa, R. O. B. \& Tang, Shou-Ching. (2010). Triple-Negative Breast Cancer: Unique Biology and Its Management, Cancer Investigation, Vol. 28, No. 8, Sep 2010, pp. 878883

Mamounas, E. P.; Jeong, J. H.; Wickerham, D. L.; Smith, R. E.; Ganz, P. A.; Land, S. R.; Eisen, A.; Fehrenbacher, L.; Farrar, W. B.; Atkins, J. N.; Pajon, E. R.; Vogel, V. G.; Kroener, J. F.; Hutchins, L. F.; Robidoux, A. ; Hoehn, J. L. ; Ingle, J. N. ; Geyer Jr., C. E.; Costantino, J. P. \& Wolmark, N. (2008). Benefit from exemestane as extended adjuvant therapy after 5 years of adjuvant tamoxifen: intention-to-treat analysis of the National Surgical Adjuvant Breast and Bowel Project B-33 trial, Journal of Clinical Oncology, Vol. 26, No 12, Apr 2008, pp. 1965-1971

Martin, M.; Villar, A.; Sole-Calvo, A.; Gonzalez, R.; Massuti, B.; Lizon, J.; Camps, C.; Carrato, A.; Casado, A.; Candel, M. T.; Albanell, J.; Aranda, J.; Munarriz, B.; Campbell, J.; Diaz-Rubio, E. \& GEICAM Group (Spanish Breast Cancer Research Group). (2003). Doxorubicin in combination with fluorouracil and cyclophosphamide (i.v. FAC regimen, day 1,21$)$ versus methotrexate in combination with fluorouracil and 
cyclophosphamide (i.v. CMF regimen, day 1,21) as adjuvant chemotherapy for operable breast cancer: a study by the GEICAM group Spain, Annals of Oncology, Vol. 14, No. 6, Jun 2003, pp. 833-842

Martin, M.; Pienkowski, T.; Mackey, J.; Pawlicki, M.; Guastalla, J. P.; Weaver, C.; Tomiak, E.; Al-Tweigeri, T.; Chap, L.; Juhos, E.; Guevin, R; Howell, A.; Fornander, T.; Hainsworth, J. ; Coleman, R. ; Vinholes, J. ; Modiano, M. ; Pinter, T. ; Tang, S. C. ; Colwell, B. ; Prady, C. ; Provencher, L. ; Walde, D. ; Rodriguez-Lescure, A. ; Hugh, J. ; Loret, C. ; Rupin, M. ; Blitz, S. ; Jacobs, P. ; Murawsky, M.; Riva, A. ; Vogel, C. \& Breast Cancer International Research Group 001 Investigators. (2005). Adjuvant docetaxel for node-positive breast cancer, The New England journal of medicine, Vol. 352, No. 22, Jun 2005, pp. 2302-2313

Martin, M.; Mackey, J. \& Pienkowski, T. et al. (2010). Ten-year follow-up analysis of the BICRG 001 trial confirms superior DFS and OS benefit of adjuvant TAC (docetaxel, doxorubicin, cyclophosphamide) over FAC (fluorouracil, doxorubicin, cyclophosphamide) in women with operable node-positive breast cancer, San Antonio Breast Cancer Symposium; December 8-12, 2010

Martin, M.; Segui, M. A.; Anton, A.; Ruiz, A.; Ramos, M.; Adrover, E.; Aranda, I.; RodriguezLescure, A.; Grosse, R. ; Calvo, L. ; Barnadas, A. ; Isla, D. ; Martinez del Prado, P.; Ruiz Borrego, M.; Zaluski, J. ; Arcusa, A. ; Munoz, M. ; Vega Lopez, J.M.; Mel, J. R.; Munarriz, B.; Llorca, C. ; Jara, C. ; Alba, E. ; Florian, J. ; Li, J. ; López GarcíaAsenjo, JA.; Saez, A.; Rios, M. J. ; Almenar, S. ; Peiro, G. \& Lluch, A. (2010). Adjuvant docetaxel for high-risk, node-negative breast cancer, The New England journal of medicine, Vol. 363, No. 23, Dec 2010, pp. 2200-2210

Montemurro, F. \& Aglietta, M. (2009). Hormone receptor-positive early breast cancer: controversies in the use of adjuvant chemotherapy, Endocrine-related cancer, Vol. 16, No. 4, Dec 2009, pp. 1091-1102

Muss, H. B.; Thor, A. D.; Berry, D. A.; Kute, T.; Liu, E. T.; Koerner, F. ; Cirrincione, C. T. ; Budman, D. R. ; Wood, W. C. \& Barcos, M et al. (1994). c-erbB-2 expression and response to adjuvant therapy in women with node-positive early breast cancer, The New England journal of medicine, Vol. 330, No 18, May 1994, pp. 1260-1266

Nittin T. T. (1996). Oncogenes, Estradiol Biotransformation, and Mammary Carcinogenesis, ANNALS NEW YORK ACADEMY OF SCIENCES, Vol. 784, Apr 1996, pp. 277-287

Norton, L. (1988). A Gompertzian model of human breast cancer growth, Cancer research, Vol. 48, No 24, Dec 1988, pp. 7067-7071

Nowak, A. K.; Wilcken, N. R.; Stockler, M. R.; Hamilton, A. \& Ghersi, D. (2004). Systematic review of taxane-containing versus non-taxane-containing regimens for adjuvant and neoadjuvant treatment of early breast cancer, The Lancet Oncology, Vol. 5, No. 6, Jun 2004, pp. 372-380

Paik, S.; Bryant, J.; Tan-Chiu, E.; Yothers, G.; Park, C.; Wickerham, D. L. \& Wolmark, N. (2000) HER2 and choice of adjuvant chemotherapy for invasive breast cancer: National Surgical Adjuvant Breast and Bowel Project Protocol B-15, Journal of the National Cancer Institute, Vol. 92, No.24, Oct 2000, pp. 1991-2000

Perez, E. A.; Romond, E. H.; Suman, V. J.; Jeong, J.; Davidson, N. E.; Geyer, C. E.; Martino, S.; Mamounas, E. P.; Kauffman, P. A. \& Wolmark, N. (2007). NCCTG/NSABP, Updated results of the combined analysis of NCCTG N9831 and NSABP B-31 adjuvant chemotherapy with/without trastuzumab in patients with HER2-positive breast cancer, Journal of clinical oncology, Vol. 25, No. 18S, Jun 2007, pp. 512

Perou, C. M.; Sørlie, T.; Eisen, M. B.; van de Rijn, M.; Jeffrey, S. S.; Rees, C. A.; Pollack, J. R.; Ross, D. T.; Johnsen, H. ; Akslen, L. A. ; Fluge, O. ; Pergamenschikov, A. ; 
Williams, C. ; Zhu , S. X. ; Lønning, P. E. ; Borresen-Dale, A. L. ; Brown, P. O. \& Botstein, D. (2000). Molecular portraits of human breast tumours, Nature, Vol. 406,No. 6797, Aug 2000, pp. 747-75

Peto, J.; Collins, N.; Barfoot, R.; Seal, S. ; Warren, W. ; Rahman, N., Easton, D. F. ; Evans, C. ; Deacon, J. \& Stratton, M. R. (1999). Prevalence of BRCA1 and BRCA2 gene mutations in patients with early-onset breast cancer, Journal of the National Cancer Institute, Vol. 91, No. 11, Jun 1999, pp. 943-949

Piccart-Gebhart, M. J.; Procter, M. \& Leyland-Jones, B. et al. for the Herceptin Adjuvant (HERA) Trial Study Team. (2005). Trastuzumab after Adjuvant Chemotherapy in HER2-Positive Breast Cancer, The New England journal of medicine, Vol. 353, No.16, Oct 2005, pp. 1659-1672

Prat, A.; Parker, J. S.; Karginova, O.; Fan, C.; Livasy, C.; Herschkowitz, J. I.; He, X. \& Perou, C. M. (2010). Phenotypic and molecular characterization of the claudin-low intrinsic subtype of breast cancer, Breast Cancer Research, Vol. 12, No. R68, Sep 2010, pp. 1-18

Regan, MM.; Viale, G.; Mastropasqua, MG.; Maiorano, E.; Golouh, R.; Carbone, A.; Brown, B.; Suurküla, M.; Langman, G.; Mazzucchelli, L.; Braye, S.; Grigolato, P.; Gelber, RD.; Castiglione-Gertsch, M.; Price, KN.; Coates, AS.; Goldhirsch, A.; Gusterson, B. \& International Breast Cancer Study Group. (2006). Re-evaluating adjuvant breast cancer trials: assessing hormone receptor status by immunohistochemical versus extraction assays, Journal of the national cancer Institute, Vol.98, No. 21, Nov 2006, pp. 1571-1581

Robert, N. J.; Eiermann, W.; Pienkowski, T.; Crown, J.; Martin, M.; Pawlicki, M.; Chan, A. ; Bee, V. ; Slamon, D. \& Au, H. on behalf of the BCIRG 006 Investigators. (2007). BCIRG 006: Docetaxel and trastuzumab-based regimens improve DFS and OS over AC-T in node positive and high risk node negative HER2 positive early breast cancer patients: Quality of life (QOL) at 36 months follow-up, Journal of Clinical Oncology, Vol. 25, No 18S, Jun 2007

Robson, M. E.; Storm, C. D.; Weitzel, J.; Wollins, D. S.; Offit, K. \& American Society of Clinical Oncology. (2010). American Society of Clinical Oncology policy statement update: genetic and genomic testing for cancer susceptibility, Journal of clinical oncology, Vol. 28, No 5, Feb 2010, pp. 893-901

Roche, H.; Fumoleau, P.; Spielmann, M.; Canon, J. L.; Delozier, T.; Serin, D.; Symann, M.; Kerbrat, P.; Soulie, P.; Eichler, F.; Viens, P. ; Monnier, A. ; Vindevoghel, A. ; Campone, M. ; Goudier, M. J. ; Bonneterre, J. ; Ferrero, J. M. ; Martin, A. L. ; Geneve, J. \& B. Asselain, Sequential adjuvant epirubicin-based and docetaxel chemotherapy for node-positive breast cancer patients: the FNCLCC PACS 01 Trial, Journal of Clinical Oncology, Vol. 24, No.36, Nov 2006, pp. 5664-5671

Romond, E. H.; Perez, E. A.; Bryant, J.; Suman, V. J.; Geyer Jr., C. E.; Davidson, N. E.; TanChiu, E.; Martino, S. ; Paik, S. ; Kaufman, P. A. ; Swain, S. M. ; Pisansky, T. M. ; Fehrenbacher, L. ; Kutteh, L. A. ; Vogel, V. G. ; Visscher, D. W. ; Yothers, G. ; Jenkins R. B. .; Brown, A. M. ; Dakhil, S. R. ; Mamounas, E. P. ; Lingle, W. L. ; Klein, P. M. ; Ingle, J. N. \& Wolmark, N. (2005). Trastuzumab plus adjuvant chemotherapy for operable HER2-positive breast cancer, The New England journal of medicine, Vol. 353, No. 16, Oct 2005, pp. 1673-1684

Santen, R. J.; Brodie, H.; Simpson, E. R.; Siiteri, P. K. \& Brodie, A. (2009) History of aromatase: Saga of an Important Biological Mediator and Therapeutic Target, Endocrine reviews, Vol. 30, No. 4, Jun 2009, pp. 343-375

Simpson, E. R. (2003). Sources of estrogen and their importance, The Journal of steroid biochemistry and molecular biology, Vol. 86, No. 3-5, Sep 2003, pp. 225-230 
Slamon, D. J.; Leyland-Jones, B.; Shak, S.; Fuchs, H.; Paton, V.; Bajamonde, A.; Fleming, T. ; Eiermann, W. ; Wolter, J. ; Pegram, M. ; Baselga, J. \& Norton, L. (2001). Use of chemotherapy plus a monoclonal antibody against HER2 for metastatic breast cancer that overexpresses HER2, The New England journal of medicine, Vol. 344, No.11, 2001, pp. 783-792

Smith, I. E.; Harris, A. L.; Morgan, M.; Gazet, J. C. \& McKinna, J. A. (1982). Tamoxifen versus aminoglutethimide versus combined tamoxifen and aminoglutethimide in the treatment of advanced breast carcinoma, Cancer research, Vol. 42, No. 8S, Aug 1982, pp. 3430s-3433s.

Smith, I.; Procter, M. \& Gelber, R.D. et al for the HERA study team. (2007) 2-year follow-up of trastuzumab after adjuvant chemotherapy in HER2-positive breast cancer: a randomized controlled trial, The Lancet, Vol. 369, No. 9555, Jan 2007, p 29-36

Smith, R. A.; Cokkinides, V.; Eyre, H. J. \& American Cancer Society, American Cancer Society guidelines for the early detection of cancer, CA: a cancer journal for clinicians, Vol. 53, No. 1, Feb 2003, pp. 27-43

Sorlie, T.; Perou, C. M.; Tibshirani, R.; Aas, T.; Geisler, S.; Johnsen, H.; Hastie, T.; Eisen, M. B.; van de Rijn, M.; Jeffrey, S. S.; Thorsen, T. ; Quist, H. ; Matese, J. C. ; Brown, P. O. ; Botstein, D. ; Lønning, PE. \& Børresen-Dale, AL. (2001). Gene expression patterns of breast carcinomas distinguish tumor subclasses with clinical implications, Proc Natl Acad Sci, Vol. 98, No. 19, Sep 2001, pp. 10869-10874

Sorlie, T.; Tibshirani, R.; Parker, J.; Hastie, T.; Marron, J. S. ; Nobel, A. ; Deng, S. ; Johnsen, H. ; Pesich, R. ; Geisler, S. ; Demeter, J. ; Perou, C. M. ; Lønning PE, Brown, P. O. ; Børresen-Dale, AL \& Botstein, D. ( 2003). Repeated observation of breast tumor subtypes in independent gene expression data sets, Proc Natl Acad Sci, Vol. 100, No 14, Jul 2003, pp. 8418-8423

Sotiriou, C. \& Pusztai, L. Gene-expression signatures in breast cancer, The New England journal of medicine, Vol. 360, No.8, Feb 2009, pp. 790-800

Takkouche, B.; Regueira-Mendez, C. \& Etmina, M. (2008). Breast cancer and use of nonsteroidal anti-inflammatory drugs: a meta-analysis, Journal of the National Cancer Institute, Vol. 100, no. 20, Oct 2008, pp. 1439-1447

The National Comprehensive Cancer Center, National Comprehensive Cancer Network-NCCN practice guidelines in oncology. Invasive breast cancer, V3, 2010, www.nccn.org

Thomas, D. B.; Gao, R. D. L.; Ray, M.; Wang, W. W.; Allison, C. J.; Chen, F. L.; Porter, P. ; Hu, Y. W. ; Zhao, G. L. ; Pan, L. D. ; Li , W; Wu, C. ; Coriaty, Z. ; Evans, I. ; Lin, M. G. ; Stalsberg, V \& Self, S. G. (2002). Randomized trial of breast self-examination in Shanghai: final results, Journal of the National Cancer Institute, Vol. 94, No. 19, Oct 2002, pp. 1445-1457

Visvanathan, K.; Chlebowski, R. T.; Hurley, P.; Col, N. F.; Ropka, M.; Collyar, D.; Morrow, M.; Runowicz, C.; Pritchard, K. I. ; Hagerty, K.; Arun, B. ; Garber, J. ; Vogel, V. G. ; Wade, J. L. ; Brown , P. ; Cuzick, J. ; Kramer, B. S. ; Lippman, S. M. \& American Society of Clinical Oncology. (2009). American society of clinical oncology clinical practice guideline update on the use of pharmacologic interventions including tamoxifen, raloxifene, and aromatase inhibition for breast cancer risk reduction, Journal of clinical oncology, Vol. 27, No. 19, Jul 2009, pp. 3235-3258

Voduc, K. D., Cheang, M. C.; Tyldesley, S.; Gelmon, K.; Nielsen, T. O. \& Kennecke, H. (2010). Breast cancer subtypes and the risk of local and regional relapse, Journal of Clinical Oncology, Vol. 28, No. 10, Apr 2010, pp. 1684-1691 


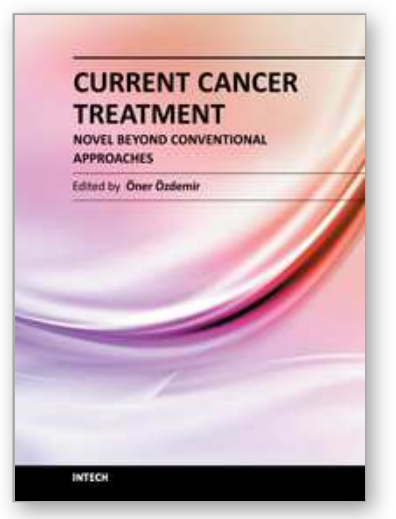

\author{
Current Cancer Treatment - Novel Beyond Conventional \\ Approaches \\ Edited by Prof. Oner Ozdemir
}

ISBN 978-953-307-397-2

Hard cover, 810 pages

Publisher InTech

Published online 09, December, 2011

Published in print edition December, 2011

Currently there have been many armamentaria to be used in cancer treatment. This indeed indicates that the final treatment has not yet been found. It seems this will take a long period of time to achieve. Thus, cancer treatment in general still seems to need new and more effective approaches. The book "Current Cancer Treatment - Novel Beyond Conventional Approaches", consisting of 33 chapters, will help get us physicians as well as patients enlightened with new research and developments in this area. This book is a valuable contribution to this area mentioning various modalities in cancer treatment such as some rare classic treatment approaches: treatment of metastatic liver disease of colorectal origin, radiation treatment of skull and spine chordoma, changing the face of adjuvant therapy for early breast cancer; new therapeutic approaches of old techniques: laser-driven radiation therapy, laser photo-chemotherapy, new approaches targeting androgen receptor and many more emerging techniques.

\title{
How to reference
}

In order to correctly reference this scholarly work, feel free to copy and paste the following:

Muaiad Kittaneh and Stefan Glück (2011). Adjuvant Therapy for Early Breast Cancer, Current Cancer Treatment - Novel Beyond Conventional Approaches, Prof. Oner Ozdemir (Ed.), ISBN: 978-953-307-397-2, InTech, Available from: http://www.intechopen.com/books/current-cancer-treatment-novel-beyondconventional-approaches/adjuvant-therapy-for-early-breast-cancer

\section{INTECH}

open science | open minds

\section{InTech Europe}

University Campus STeP Ri

Slavka Krautzeka 83/A

51000 Rijeka, Croatia

Phone: +385 (51) 770447

Fax: +385 (51) 686166

www.intechopen.com

\section{InTech China}

Unit 405, Office Block, Hotel Equatorial Shanghai

No.65, Yan An Road (West), Shanghai, 200040, China

中国上海市延安西路65号上海国际贵都大饭店办公楼 405 单元

Phone: +86-21-62489820

Fax: $+86-21-62489821$ 
(C) 2011 The Author(s). Licensee IntechOpen. This is an open access article distributed under the terms of the Creative Commons Attribution 3.0 License, which permits unrestricted use, distribution, and reproduction in any medium, provided the original work is properly cited. 